\title{
Characterization and Classification of Paddy and Associated Non Paddy Soils of Upper Brahmaputra Valley of Assam
}

\author{
By Zenesia A. Phillips, Dr. R. M Karmakar \& Dr. S. Dutta
}

Abstract- An investigation was done to characterize and classify paddy and associated nonpaddy soils of the Upper Brahmaputra Valley of Assam. In this study, three districts viz., Sivasagar, Jorhat, and Golaghat in the Brahmaputra valley of Assam were selected. These districts are located in the Upper Brahmaputra Valley Zone (UBV) of Assam. Combined, they cover an approximate area of $9021 \mathrm{sq}$. Km or about 55.7 per cent of UBV. Six soil profiles, three each from mono-cropped paddy and, associated nonpaddy areas were collected from the districts mentioned. These samples were collected Horizon wise from each soil profile. Each soil sample was dried and passed through a $2 \mathrm{~mm}$ sieve. The samples from each pedon were evaluated for morphological and Physicochemical characteristics, based on morphological and physicochemical properties. The soils were classified as Aquic Dystric Eutrudepts (P1), Dystric Eutrudepts (NP1, NP2, P3, NP3) and Dystric Fluventic Eutrudepts (P2).

Keywords: mono-cropped, morphological, physic-chemical, horizon, pedon.

GJSFR-D Classification: FOR Code: 050399, 070199

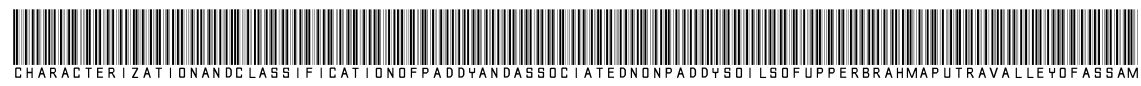

Strictly as per the compliance and regulations of:

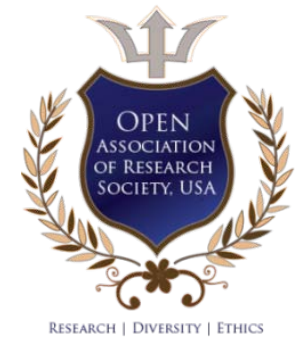

(C) 2020. Zenesia A. Phillips, Dr. R. M Karmakar \& Dr. S. Dutta. This is a research/review paper, distributed under the terms of the Creative Commons Attribution-Noncommercial 3.0 Unported License http://creativecommons.org/licenses/by-nc/3.0/), permitting all non commercial use, distribution, and reproduction in any medium, provided the original work is properly cited. 


\title{
Characterization and Classification of Paddy and Associated Non Paddy Soils of Upper Brahmaputra Valley of Assam
}

\author{
Zenesia A. Phillips ${ }^{\alpha}$, Dr. R. M Karmakar ${ }^{\circ} \&$ Dr. S. Dutta ${ }^{\rho}$
}

\begin{abstract}
An investigation was done to characterize and classify paddy and associated nonpaddy soils of the Upper Brahmaputra Valley of Assam. In this study, three districts viz., Sivasagar, Jorhat, and Golaghat in the Brahmaputra valley of Assam were selected. These districts are located in the Upper Brahmaputra Valley Zone (UBV) of Assam. Combined, they cover an approximate area of $9021 \mathrm{sq}$. $\mathrm{Km}$ or about 55.7 per cent of UBV. Six soil profiles, three each from mono-cropped paddy and, associated nonpaddy areas were collected from the districts mentioned. These samples were collected Horizon wise from each soil profile. Each soil sample was dried and passed through a $2 \mathrm{~mm}$ sieve. The samples from each pedon were evaluated for morphological and Physicochemical characteristics, based on morphological and physicochemical properties. The soils were classified as Aquic Dystric Eutrudepts (P1), Dystric Eutrudepts (NP1, NP2, P3, NP3) and Dystric Fluventic Eutrudepts (P2).
\end{abstract}

Keywords: mono-cropped, morphological, physicchemical, horizon, pedon.

\section{INTRODUCTION}

S oils show diverse behavior owing to differences in pedogenic pathways they have gone through in the course of pedogenesis. The pedogenic processes has been reflected in soil morphological, physicochemical, mineralogical, and other properties. Collecting soil information through a systematic soil survey is a prudent way of registering the holistic picture of the behavior of soils in a particular area. Information gathered tells about soil morphology, genesis, properties, and classification (M. Balthazar, et al., 2016).

Morphology of the soils is an expression of the effect of soil-forming factors and processes. The formation of paddy soils has been induced by the practice of puddling, followed by flooding and drainage regime, which leads to the development of a plow-pan and specific redoximorphic features of the soil (KogelKnabner et al., 2010). Change in soil were caused by artificial hydromorphism, normally associated with rice cultivation, which is the change in dominant soil colour from brown to gray (with chroma $<2$ ) with the presence of mottles, higher in chroma (Kanno, 1956). The pattern of gray colour formation in paddy soils varied according to water management and ground water hydrology

Author: Division of soil science, Assam Agricultural University - Jorhat 785013, India.e-mail: zenesia_phillips@yahoo.com
(Moormann and van Breeman, 1978). The colour of rice growing soils of Assam ranged from very pale brown to gray (Baruah et al., 1996; Dey 1987) with the occurrence of mottles of higher chroma (6-8) and low chroma $(<2)$ which are indicative of hydromorphic characteristics (Das, 1990).

Typical paddy growing soils of Assam have characteristic plow-pans with high bulk densities (Das, 1990). Gangopadhyay et al. (1998) observed that the texture of rice growing soils of upper Assam varied from sandy loam in the surface to sandy loam and loam to sand in the subsurface horizons. Dutta (2001) reported that the texture of the paddy and non-paddy soils varied from sandy clay loam to clay and from sandy loam to clay loam respectively.

Puddling in paddy soils is the most common method of rice cultivation, which damages soil structure in plow-layer of these soils and decreases pores and voids in this layer (Hassannezhad et al., 2008). Puddling leads to deteriorated soil physical properties by breaking down soil aggregates and forming hardpans at shallow depths in paddy soils. This practice leads to induced changes in pore size distribution; and the increase in bulk density (BD) of the soil (Zhou et al., 2014). The structure of rice growing soils of the Brahmaputra valley of Assam was massive in the surface and weak to moderately develop in the surface horizons (Das, 1990; Baruah et al., 1996). Plow-sole was reported to form in medium-textured and well drained Latosol (Grant, 1965) but absent in sandy young alluvial, calcareous soils (Moormann and Dudal, 1964) and in much fined textured soils (Stout, 1966). Fukushi and Iwama (1982) confirmed that plow-sole formation steadily deceases from well drained to poorly drained soils.

The paddy soils developed on recent alluvium was reported to have lower clay content in the surface (Kanno et al., 1964; Somasiri, 1985). In strongly acid soils, seasonal wetting, and drying causes breakdown of clay by a process called ferrolysis, resulting in lower clay content in the surface soils (Brinkman, 1970).

\section{il. Physicochemical Characteristics}

An understanding of the physical and chemical conditions of any soil is necessary for the proper 
implementation of soil management practices. Therefore, the study of soil physicochemical properties is necessary, since it affects soil productivity. Physicochemical study of soil were based on various parameters, which included; $\mathrm{pH}$, bulk density, electrical conductivity, texture, moisture, temperature, soil organic matter, available nitrogen, phosphorus and, potassium (Tale and Indole, 2015).

There are several reports that paddy cultivation increases the bulk density of surface layer and leads to the formation of plow-sole of higher bulk density (Motomura et al., 1970; Meelu et al., 1979). Studies by Kurniati et al. (2015) suggested that generally, paddy soils had a higher value than dry soil. Paddy profiles showed a plow- pan layer found below the top soil. This layer showed an increase in bulk density value as compared to that of top soil or layers below. This was mainly attributed to the puddling process during rice cultivation.

Motomura et al. (1970) and Mitsuchi (1974) observed a significant increase in organic matter content in the lowland paddy soils and yellow paddy soils, and the effect of cultivation was recognized only in the surface horizon. Similar observations had been made on the paddy soils of China (Okajima and Imai, 1981; Xi, 1981). On the contrary, several workers reported a decrease in organic matter content in surface layers of paddy soils (Van Veen et al., 1984; Katou et al., 1985). Dey and Sehgal (1997) reported that organic matter content was lower in paddy, than the associated non-paddy soils due to repeated cycles of wetting and drying. Zhang and Chen (2009) reported that surface soil organic carbon and $\mathrm{CaCO}_{3}$ had notable changes within the initial stage (50 yrs) of paddy cultivation. Clay content and free iron oxides changed notably, when paddy cultivation history reached 700 years. The results of gains and losses of key elements indicate $\mathrm{Ca}, \mathrm{Mg}$, and $\mathrm{Na}$ are strongly lost in the initial stage (50 yrs) of paddy cultivation and gradually depleted with increasing paddy cultivation over time. The decomposition of organic matter is less efficient under anaerobic conditions during the anthropogenic submergence of paddy top soils, resulting in more accumulation of organic matter relative to the nonpaddy top soils (Kalbitz, et al., 2013).

It has been known that in paddy soils, the overall effect of submergence is to increase the $\mathrm{pH}$ of the acid soils and to decrease the $\mathrm{pH}$ of the alkaline soils. The increase in $\mathrm{pH}$ of acid soil is mainly due to the reduction of ferric oxides and oxyhydroxides (Ponnamperuma et al., 1966). But after the harvest of rice, the $\mathrm{pH}$ of the paddy soils becomes acidic. Prasad and Jondhale (2006) observed that rice soils had lower $\mathrm{pH}$ and higher organic matter content than their nongrowing counterparts, with minor amounts of $\mathrm{Ca}$ and $\mathrm{Mg}$ ions as compared to non-paddy soils. Further studies have shown that $\mathrm{pH}$ in paddy soil was higher than $\mathrm{pH}$ from dry land. Flooded soil causes increased bases solubility, so the concentration of $\mathrm{H}+$ in the soil was reduced. Increasing the $\mathrm{pH}$ in acid soils as a result of flooding is controlled by system $\mathrm{Fe} 2+-\mathrm{Fe}(\mathrm{OH})$ that consumes $\mathrm{H}+$ (Kurniati et al., 2015).

Paddy soils exhibited higher CEC than the associated nonpaddy profiles (Dutta, 2001). Baruah et al. (1996) also reported exchangeable $\mathrm{H}^{+}$as the dominant acid cation in surface soils of the rice- growing areas of the Brahmaputra valley of Assam. This finding has been corroborated by the findings of Dutta (2001). Traditional Paddy and nonpaddy soils of Brahmaputra and Barak valley of Assam have been studied for their physical and chemical characteristics and classification by Dey and Sehgal (1997). They reported that organic carbon and cation exchange capacity to clay ratio were lower in the surface horizon of paddy soils as compared to non-paddy associates. They also found that paddy soils were characterized by a lesser amount of mica in both fine sand and silt fractions and of olivines in silt fractions as compared to that of nonpaddy associates in their surface horizons. It has been reported that paddy soils contained relatively more amounts of total, dithionite, and oxalate extractable Al than the associated nonpaddy soils (Dutta, 2001). Paddy soils generally contained higher amount of silicate and amorphous inorganic forms of $\mathrm{Fe}$ and $\mathrm{Al}$ and a lower amount of crystalline formations of $\mathrm{Fe}$ and $\mathrm{Al}$ as compared to the nonpaddy soils (Dutta 2001).

\section{ili. Materials and Methods}

The information about the study area as well as the methods utilized in the present investigation has been described below:

\section{a) Location and extent}

The three districts that were selected for this study were, Sivasagar, Jorhat and, Golaghat, which were all located in the Brahmaputra valley of Assam. These districts are situated in the Upper Brahmaputra Valley Zone (UBV) of Assam covering just about 55.7 percent of UBV with an area of about 9021 sq. Km. These districts together form a part of the southern bank of the Brahmaputra valley of Assam. The district of Sivasagar lies between $26^{\circ} 27^{\prime} \mathrm{N}$ and $27^{\circ} 9^{\prime} \mathrm{N}$ latitudes and $94^{\circ} 15^{\prime} \mathrm{E}$ and $95^{\circ} 15^{\prime} \mathrm{E}$ longitudes. It is bounded on the north by the Brahmaputra River, on the south by Naga Hills, on the east by Dibrugarh district, and on the west by Jorhat district. The total geographical area of the district is $2668 \mathrm{sq} . \mathrm{km}$. The district of Jorhat is situated between $26^{\circ} 20^{\prime} \mathrm{N}$ to $27^{\circ} 10^{\prime} \mathrm{N}$ latitudes and $93^{\circ} 57^{\prime} \mathrm{E}$ to $94^{\circ} 37 \mathrm{E}$ longitudes in the eastern part of Assam. It is bounded by North Lakhimpur district in the north, Nagaland in the south and south-east, Sivasagar district in the east and Golaghat district in the west. The total geographical area of the district is 2853.332 sq. $\mathrm{Km}$. The district of Golaghat is situated between $26^{\circ} \mathrm{N}$ 
to $27^{\circ} \mathrm{N}$ latitudes and $93^{\circ} \mathrm{E}$ to $94^{\circ} 18^{\prime} \mathrm{E}$ longitudes. It is bounded by the river Brahmaputra in the north, Nagaland in the south, Jorhat district in the east and, Karbi Anglong district in the west. The total geographical area of the district is 3540.7 sq. Km.

\section{b) Geology}

The Brahmaputra valley is a part of the IndoGangetic Brahmaputra river system of North East India, covering an area of $56,570 \mathrm{sq} . \mathrm{Km}$. The study area takes up approximately 15.95 percent of the Brahmaputra Valley. This valley had been formed during the Pleistocene and in recent periods from the sediments brought down from the Assam Plateau in the south and Assam Himalayas in the north (Wadia, 1966). The geological nature of the deposits brought down by the river is quite different from that deposited by the tributaries flowing down from the foothills on both sides resulting in the formation of different types of alluvium. These districts consist mainly of substantial thickness of recent alluvium and tertiary rocks.

\section{c) Climate}

The climate of the study area is humid subtropical. This condition had been influenced mainly by the southwest monsoon from the Bay of Bengal and determined by the surrounding hills of Assam. Mean annual rainfall of Sivasagar, Jorhat, and Golaghat districts are 2119.8, 1919.3, and $1743.0 \mathrm{~mm}$ respectively. The mean annual temperatures in these districts are 23.4, 23.8 and $23.7 \mathrm{C}$, respectively. The mean maximum and minimum temperatures in these districts vary from 28.3 to $29.0 \mathrm{C}$ and 18.0 to $19.3 \mathrm{C}$, respectively. The difference between mean summer and mean winter o temperatures in the study area is $>5 \mathrm{C}$. The soil moisture and temperature regimes in these districts are udic and hyperthermic, respectively.

\section{Location of Sampling Sites}

Six soil profiles were dug following the collection of soil samples, three samples each from monocropped paddy and associated non-paddy areas had been collected from Sivasagar, Jorhat and Golaghat districts of Assam. Samples had been collected Horizon-wise from each soil profile. Details of location and site information of the study has been given in Table 1.

Table 1: Location and site characteristics of studied profiles

\begin{tabular}{cccccc}
\hline Si. No. & Location & Lithology & Physiography & Land use & Slope \\
\hline P1 & Nimaigarh Habigaon & Alluvium & Alluvial plain & Paddy cultivation & $0-3$ \\
P2 & Nimaigarh Habigaon & Alluvium & Alluvial plain & Non-paddy, Fallow & $0-3$ \\
P3 & Silikha Sanaton & Alluvium & Alluvial plain & Paddy cultivation & $0-3$ \\
P4 & Silikha Sanatongaon & Alluvium & Alluvial plain & Non-paddy, Fallow & $0-3$ \\
P5 & Khumtai & Alluvium & Alluvial plain & Paddy cultivation & $0-3$ \\
P6 & Khumtai & Alluvium & Alluvial plain & Non-paddy, Fallow & $0-3$ \\
\hline
\end{tabular}

\section{a) Preparation of soil samples}

The soil samples were firstly air-dried, and ground before being passed through a $2 \mathrm{~mm}$ sieve. The sieved soil samples were then stored in polythene bags and later utilized for various physicochemical analyses. Fresh soil samples had been stored a refrigerator for the purpose of carrying out microbiological analyses.

\section{b) Physicochemical analysis}

Morphological features of each pedon had been studied in the field following standard procedure (All India Soil and Land Use Survey Organization, 1971). Conventional methods had been adopted for physicochemical and microbiological analyses which has been presented in Table 2 .

Table 2: Methods adopted for morphological and Physico- chemical analysis

\begin{tabular}{clll}
\hline Si. No. & \multicolumn{1}{c}{ Parameters } & \multicolumn{1}{c}{ Methods } & \multicolumn{1}{c}{ Reference } \\
\hline 1 & Mechanical analysis & International Pipette Method & Piper (1966) \\
2 & Soil reaction (1:2.5) & Glass electrode pH meter & Jackson (1973) \\
3 & Electrical conductivity (1:2.5) & Electrical conductivity meter & Jackson (1973) \\
4 & Organic carbon & Walkley and Black's method & Jackson (1973) \\
\hline 5 & Cation exchange capacity & Distillation method & Jackson (1973) \\
6 & Percent base saturation & & \\
7 & Available nitrogen & Alkaline KMnO4 method (1956) & Subbiah and Asija (1956) \\
8 & Available phosphorous & Extracted with 0.03N NH4F in & Bray and Kurtz (1945) \\
& Available potassium & F.025 N HCl (Bray's-I method). & \\
9 & Bulk density & Clame photometric method & Jackson (1973) \\
\hline 10 & & & Black (1965) \\
\hline
\end{tabular}




\section{Results and Discussion}

\section{a) Morphological characteristics}

The morphological characteristics of the soils have been given in Table 3. Soil color varied from light olive-brown to yellow. The hue of soil color ranged from 2.5Y to 10YR, with 10YR being most dominant. Dominant hue of 10YR in soils of Assam had been reported by Chakravarty et al. (2008), Karmakar and, Rao (1999a). The yellower color of soil, 2.5Y was observed only below $55 \mathrm{~cm}$ depth of $\mathrm{P} 2$ under paddy cultivation. The value ranged from 5 to 8 and chroma from 1 to 8 . Chroma of 2 or less observed in subsurface horizons of P1, NP1 and, P3 indicate aquic conditions and the process of gleization operating in these soils. Few, fine, distinct to common, medium, prominent mottles with colors of $7.5 \mathrm{YR} 6 / 8$ to $7.5 \mathrm{YR} 8 / 8$ had been observed in some subsurface horizons of the studied soils. Mottles with higher chroma are said to be associated with rice cultivation (Kanno, 1956) and are indicative of hydromorphic conditions (Das, 1990).

The soil textural class varied from loamy sand to clay loam. Such types of textural variations in paddy and non-paddy soils of Assam have been reported earlier (Dey and Sehgal, 1997: Gangopadhyay et al., 1998). The soil structure varied from massive to sub-angular blocky. Surface horizons of paddy soils exhibited massive structure. This structure in the surface horizons of paddy soils was due to the destruction of soil structure during puddling. This practice damages soil structure in the plow-layer of paddy soils and decreases pores and voids in this layer. (Hassannezhad et al., 2008). Medium, weak to strong sub angular structure, had been observed in the soils. The consistence noted in the studied soils ranged from being slightly hard to hard, very friable to firm, slightly sticky and, slightly plastic.

Table 3: Morphological characteristics of the soils

\begin{tabular}{|c|c|c|c|c|c|c|}
\hline Horizon & Depth (cm) & $\begin{array}{l}\text { Soil colour } \\
\text { (moist) }\end{array}$ & Mottling & Texture & Structure & Consistence \\
\hline \multicolumn{7}{|c|}{ P1 (Nimaigarh Habigaon - Paddy soil) : Aquic Dystric Eutrudepts } \\
\hline Ap & $0-15$ & 10YR 6/8 & & Clay loam & massive & dsh, mfr, wss, wps \\
\hline Bw1 & $15-40$ & 10YR 6/2 & 7.5YR 7/6 f1d & Clay loam & m2sbk & dh, mfi, ws, wp \\
\hline Bw2 & $40-100$ & 10YR $7 / 3$ & 7.5YR 7/6 c2d & Clay loam & m3sbk & dh, mfi, ws, wp \\
\hline $2 \mathrm{Cg}$ & $100-120$ & 10YR 7/2 & 7.5YR 7/6 c2d & Clay loam & m2sbk & dsh, mfr, wss, wps \\
\hline \multicolumn{7}{|c|}{ NP1 (Nimaigarh Habigaon - Non-paddy soil): Dystric Eutrudepts } \\
\hline Ap & $0-33$ & 10YR 6/4 & & Clay loam & m1sbk & dsh, mfr, wss, wps \\
\hline Bw1 & $33-55$ & 10YR 5/3 & & Clay loam & m2sbk & dsh, mfr, wss, wps \\
\hline Bw2 & $55-80$ & 10YR 7/2 & & Clay loam & m3sbk & dh, mfi, ws, wp \\
\hline Bw3 & $80-100$ & 10YR 6/3 & & Clay loam & m2sbk & dsh, mfr, wss, wps \\
\hline 2Cg1 & $100-190$ & 10YR $7 / 2$ & 7.5YR 7/8 f1d & Sandy Clay loam & m2sbk & dsh, mfr, wss, wps \\
\hline 2Cg2 & $190-220$ & 10YR $7 / 1$ & 7.5YR 7/8 c2d & Clay loam & m2sbk & dsh, mfr, wss, wps \\
\hline \multicolumn{7}{|c|}{ P2 (Silikha Sanaton - Paddy soil): Dystric Fluventic Eutrudepts } \\
\hline Ap & $0-15$ & 10YR 5/4 & & Sandy loam & massive & dsh, mfr, wss, wps \\
\hline Bw & $15-55$ & 10YR 6/6 & & Sandy clay loam & m1sbk & dsh, mfr, wss, wps \\
\hline $\mathrm{Bg} 1$ & $55-90$ & $2.5 Y 6 / 4$ & 7.5YR 6/8 f1p & Clay loam & m2sbk & dh, mfi, ws, wp \\
\hline $\mathrm{Bg} 2$ & $90-125$ & $2.5 Y 5 / 4$ & 7.5YR 6/8 c2p & Clay loam & m2sbk & dsh, mfr, wss, wps \\
\hline \multicolumn{7}{|c|}{ NP2 (Silikha Sanaton - Non-paddy soil): Dystric Eutrudepts } \\
\hline A & $0-10$ & 10YR 6/4 & & Sandy clay loam & f2sbk & ds, mvfr, wss, wps \\
\hline Bw1 & $10-35$ & 10YR 6/4 & & Sandy clay loam & m2sbk & dsh, mfr, wss, wps \\
\hline Bw2 & $35-90$ & 10YR 6/6 & & Sandy clay loam & m2sbk & dsh, mfr, wss, wps \\
\hline $2 \mathrm{C} 1$ & $90-115$ & 10YR 6/8 & 7.5YR 6/8 f1d & Loamy sand & massive & ds, mvfr, wss, wps \\
\hline $3 \mathrm{C} 2$ & $115-165$ & 10YR 6/4 & & Sandy loam & massive & ds, mvfr, wss, wps \\
\hline
\end{tabular}

\begin{tabular}{|c|c|c|c|c|c|c|}
\hline Horizon & Depth $(\mathrm{cm})$ & $\begin{array}{l}\text { Soil colour } \\
\text { (moist) }\end{array}$ & Mottling & Texture & Structure & Consistence \\
\hline \multicolumn{7}{|c|}{ P3 (Khumtai - Paddy soil): Dystric Eutrudepts } \\
\hline Ap & $0-15$ & 10YR 6/3 & & Sandy clay loam & massive & dsh, mfr, wss, wps \\
\hline Bw1 & $15-50$ & 10YR 6/4 & & Sandy clay loam & m2sbk & dsh, mfr, wss, wps \\
\hline Bw2 & $50-100$ & 10YR $7 / 4$ & 7.5YR $7 / 8 \mathrm{c} 1 \mathrm{~d}$ & Clay loam & m3sbk & dh, mfi, ws, wp \\
\hline
\end{tabular}




\begin{tabular}{|c|c|c|c|c|c|c|}
\hline Bw3 & $100-165$ & 10YR 8/4 & 7.5YR 7/8 c2d & Clay loam & m3sbk & dh, mfi, ws, wp \\
\hline $\mathrm{Bg}$ & $165-190$ & 10YR 6/2 & 7.5YR 6/8 c3d & Clay loam & m2sbk & dsh, mfr, wss, wps \\
\hline \multicolumn{7}{|c|}{ NP3 (Khumtai - Non-paddy soil): Dystric Eutrudepts } \\
\hline $\mathrm{Ap}$ & $0-20$ & 10YR 6/6 & & Sandy Clay loam & m1sbk & dsh, mfr, wss, wps \\
\hline$A B$ & $20-27$ & 10YR $7 / 8$ & & Sandy clay loam & m2sbk & dsh, mfr, wss, wps \\
\hline Bw1 & $27-60$ & 10YR 7/8 & 7.5YR 6/8 f1d & Clay loam & m2sbk & dh, mfi, ws, wp \\
\hline Bw2 & $60-95$ & 10YR 7/8 & 7.5YR 8/8 c2d & Clay loam & m3sbk & dh, mfi, ws, wp \\
\hline Bw3 & $95-125$ & 10YR 6/8 & 7.5YR 8/8 c2d & Clay loam & m2sbk & dsh, mfr, wss, wps \\
\hline
\end{tabular}

\section{Vi. Physico-Chemical Characteristics}

a) Mechanical composition of soils

A perusal of particle size distribution data in Table 4 shows that the sand content of the soils varied from 29.5-60.9 percent in surface and 27.5-55.8 percent in the subsurface horizons of paddy profiles, and 31.856.4 percent in surface and 27.0-84.2 percent in the subsurface horizons of nonpaddy soils. The sand content seemed to increase with depth in P1 (paddy) and, NP1, NP2 (nonpaddy) soils decreased with depth in $\mathrm{P} 2, \mathrm{P} 3, \mathrm{NP} 3$.

The silt content of the soils varied from 20.035.0 percent in surface and 18.6-35.5 percent in the subsurface horizons of paddy soils, and 21.1-38.1 percent in the surface and 8.2-40.5 percent in the subsurface horizons of nonpaddy soils. The silt content increased with soil depth in both paddy and non-paddy soils of Khumtai (P3, NP3). In other soils depth distribution of silt content was irregular. Such type of sand and silt distribution in soil profiles is persistent in soils formed on alluvium.

The clay content of the soils varied from 18.735.5 percent in surface and 25.6-38.5 percent in the subsurface horizons of paddy soils, and 22.5-30.1 percent in the surface and 7.6-33.5 percent in the subsurface horizons of nonpaddy soils. The paddy soils developed on recent alluvium has been reported to have lower clay content on the surface (Kanno et al., 1964; Somasiri, 1985). In strongly acid soils, seasonal wetting and, drying cause breakdown of clay by a process called ferrolysis, resulting in lower clay content in the surface soils (Brinkman, 1970). Ferrolysis is a hydromorphic soil process where soil pores become water logged extensive periods of time. Excess moisture conditions slow down the process for clay formation as the anaerobic conditions are less favorable.

The amount of clay increased with soil depth, reached a maximum value, and decreased after that. Such type of distribution is indicative of moderate development of soils (Barshad, 1964). These observations indicated that silt and clay had been formed from transformation of sand fraction and or biosynthesis of clay. The profiles of Nimaigarh Habigaon (P1, NP1) contained a maximum amount of clay (27.037.0 percent) which was followed by the soils of Khumtai (22.5-32.5 percent), and Silikhasanaton (7.631.3 percent). This amount increased with soil depth, reached a maximum value and, then decreased. Sand/silt and silt/ (silt + clay) ratios changed abruptly at a dept below $100 \mathrm{~cm}$ of NP1 and below $90 \mathrm{~cm}$ of NP2, which suggested stratification or lithological discontinuity in these soils.

Table 4: Mechanical composition (\%) of the soils (particle size in $\mathrm{mm}$ )

\begin{tabular}{|c|c|c|c|c|c|c|}
\hline Horizon & Depth (cm) & $\begin{array}{l}\text { Sand } \\
(2-0.05)\end{array}$ & $\begin{array}{c}\text { Silt } \\
(0.05-0.002)\end{array}$ & $\begin{array}{c}\text { Clay } \\
(<0.002)\end{array}$ & Sand / Silt & Silt / Silt+clay \\
\hline \multicolumn{7}{|c|}{ P1 (Nimaigarh Habigaon - Paddy soil) : Aquic Dystric Eutrudepts } \\
\hline Ap & $0-15$ & 29.5 & 35.0 & 35.5 & 0.84 & 0.50 \\
\hline Bw1 & $15-40$ & 27.5 & 35.5 & 37.0 & 0.77 & 0.49 \\
\hline Bw2 & $40-100$ & 29.5 & 32.0 & 38.5 & 0.92 & 0.45 \\
\hline $2 \mathrm{Cg}$ & $100-120$ & 35.5 & 35.0 & 29.5 & 1.01 & 0.54 \\
\hline \multicolumn{7}{|c|}{ NP1 (Nimaigarh Habigaon - Non-paddy soil): Dystric Eutrudepts } \\
\hline Ap & $0-33$ & 31.8 & 38.1 & 30.1 & 0.83 & 0.56 \\
\hline Bw1 & $33-55$ & 27.0 & 40.5 & 32.4 & 0.67 & 0.54 \\
\hline Bw2 & $55-80$ & 26.8 & 39.7 & 33.5 & 0.67 & 0.56 \\
\hline Bw3 & $80-100$ & 34.1 & 36.4 & 29.5 & 0.94 & 0.55 \\
\hline 2Cg1 & 100-190 & 47.1 & 24.6 & 28.3 & 1.91 & 0.47 \\
\hline 2Cg2 & 190-220 & 36.5 & 36.5 & 27.0 & 1.00 & 0.57 \\
\hline \multicolumn{7}{|c|}{ P2 (Silikha Sanaton - Paddy soil): Dystric Fluventic Eutrudepts } \\
\hline Ap & $0-15$ & 60.9 & 20.4 & 18.7 & 2.98 & 0.52 \\
\hline Bw & $15-55$ & 55.8 & 18.6 & 25.6 & 3.00 & 0.42 \\
\hline Bg1 & 55-90 & 44.3 & 24.3 & 31.3 & 1.82 & 0.44 \\
\hline Bg2 & $90-125$ & 40.3 & 29.9 & 29.8 & 1.35 & 0.50 \\
\hline
\end{tabular}




\begin{tabular}{|ccccccc|}
\hline NP2 (Silikha Sanaton - Non-paddy soil): & Dystric & Eutrudepts & & & \\
\hline Ap & $0-10$ & 53.6 & 22.3 & 24.1 & 2.40 & 0.48 \\
Bw1 & $10-35$ & 49.5 & 22.3 & 28.2 & 2.22 & 0.44 \\
Bw2 & $35-90$ & 50.5 & 22.9 & 26.6 & 2.20 & 0.46 \\
2C1 & $90-115$ & 84.2 & 8.2 & 7.6 & 10.27 & 0.52 \\
3C2 & $115-165$ & 78.2 & 8.6 & 13.2 & 9.09 & 0.39 \\
\hline P3 (Khumtai - Paddy soil): Dystric Eutrudepts & & & & 0.42 \\
\hline Ap & $0-15$ & 52.5 & 20.0 & 27.5 & 2.63 & 0.42 \\
Bw1 & $15-50$ & 46.5 & 25.0 & 28.5 & 1.60 & 0.37 \\
Bw2 & $50-100$ & 47.0 & 22.5 & 30.5 & 1.73 & 0.46 \\
Bw3 & $100-165$ & 40.0 & 27.5 & 32.5 & 1.45 & 0.50 \\
Bg & $165-190$ & 40.0 & 30.0 & 30.0 & 1.33 & 0.48 \\
\hline NP3 (Khumtai - Non-paddy soil): Dystric Eutrudepts & & & 0.44 \\
\hline Ap & $0-20$ & 56.4 & 21.1 & 22.5 & 2.67 & 0.53 \\
AB & $20-27$ & 55.0 & 20.0 & 25.0 & 2.75 & 0.46 \\
Bw1 & $27-60$ & 40.5 & 31.5 & 28.0 & 1.29 & 0.52 \\
Bw2 & $60-95$ & 39.5 & 28.0 & 32.5 & 1.41 & 1.38 \\
Bw3 & $95-125$ & 41.7 & 30.1 & 28.2 & & \\
\hline
\end{tabular}

b) Organic C, bulk density, $\mathrm{pH}$ and, E.C.

The data on soil organic carbon content (Table 5.) show that the organic carbon content in soil varied from $5.40-7.90 \mathrm{~g} \mathrm{~kg}^{-1}$ in the surface and $0.90-6.30 \mathrm{~g} \mathrm{~kg}^{-1}$ in the subsurface horizons. The amount of organic carbon was lower (5.40-6.20 $\left.\mathrm{g} \mathrm{kg}^{-1}\right)$ in the surface horizons of paddy soils after comparisons were made to that of the surface horizons of nonpaddy soils (5.70-7.90 $\left.\mathrm{g} \mathrm{kg}^{-1}\right)$. These findings are in corroboration with those of Van Veen et al. (1984) and Katou et al. (1985), who reported a decrease in organic matter content in surface layers of paddy soils. Dey and Sehgal (1997) also published lower organic matter content in paddy soils than the associated non-paddy soils of Assam due to repeated cycles of wetting and drying, which mineralize the organic matter in the soil. The amount of organic carbon was higher in the surface horizon of all studied profiles, and it decreased with soil depth. The surface horizon of NP1 contained the highest amount of organic carbon $\left(7.90 \mathrm{~g} \mathrm{~kg}^{-1}\right)$ as compared to other soils.

Bulk density of soils ranged from about 1.12$1.42 \mathrm{~g} / \mathrm{cc}$ in the surface and 1.17-1.70 $\mathrm{g} / \mathrm{cc}$ in the subsurface horizons. The bulk density was lower in the surface horizon of all studied profiles, and it increased with soil depth. This condition may have been due to more aggregation on soil surface horizons as well as the presence of more clay. Puddling on paddy soils breaks down aggregates and increases porosity, thereby decreasing bulk density. The $\mathrm{pH}$ of the profiles (1:2.5 soil: water ratio) was in the acidic range, and varied from 4.6-5.7 in the surface, and 4.7-6.0 in the subsurface horizons. The surface horizons of paddy soils did not show higher $\mathrm{pH}$ than that of nonpaddy profiles. Though submergence increases the $\mathrm{pH}$ of acid soil during rice cultivation due to the reduction of ferric oxides and oxyhydroxides (Ponnamperuma et al. 1966), the samples collected for the study were after the harvest of rice (oxidative condition) during which $\mathrm{pH}$ of the soils becomes acidic. Prasad and Jondhale (2006) also observed similar results in their study. The reduction of $\mathrm{pH}$ values of the paddy soil also suggests that the decreased organic matter content observed in the surface horizons contributed to an acidic soil $\mathrm{pH}$. The electrical conductivity of the soils was low varying from 0.09 to $0.33 \mathrm{dSm}^{-1}$, as reflected in tables 5 . This suggests the presents of soluble salts in all soil profiles were generally low.

Table 5: Organic carbon, bulk density, $\mathrm{pH}, \mathrm{EC}$ and available nitrogen, phosphorus and potash of the soils

\begin{tabular}{|c|c|c|c|c|c|c|c|c|}
\hline \multirow{2}{*}{ Horizon } & \multirow{2}{*}{ Depth (cm) } & \multirow{2}{*}{ O.C. $\left(\mathrm{g} \mathrm{kg}^{-1)}\right.$} & \multirow{2}{*}{$\begin{array}{l}\text { Bulk density } \\
\text { g/cc }\end{array}$} & \multirow{2}{*}{$\begin{array}{c}\mathrm{pH}(1: 2.5 \\
\left.\mathrm{H}_{2} \mathrm{O}\right)\end{array}$} & \multirow{2}{*}{$\begin{array}{l}\text { E.C. }(1: 2.5 \\
\left.\mathrm{H}_{2} \mathrm{O}\right)\left(\mathrm{dSm}^{-1}\right)\end{array}$} & \multicolumn{3}{|c|}{ Available $\left(\mathrm{kg} \mathrm{ha}^{-1}\right)$} \\
\hline & & & & & & $\mathrm{N}$ & $\mathrm{P}_{2} \mathrm{O}_{5}$ & $\mathrm{~K}_{2} \mathrm{O}$ \\
\hline \multicolumn{9}{|c|}{ P1 (Nimaigarh Habigaon - Paddy soil) : Aquic Dystric Eutrudepts } \\
\hline Ap & $0-15$ & 7.30 & 1.34 & 4.6 & 0.23 & 279.1 & 28.2 & 257.6 \\
\hline Bw1 & $15-40$ & 4.70 & 1.38 & 5.4 & 0.23 & 272.8 & 23.1 & 241.8 \\
\hline Bw2 & $40-100$ & 1.50 & 1.57 & 5.9 & 0.16 & 269.7 & 20.5 & 197.2 \\
\hline $2 \mathrm{Cg}$ & $100-120$ & 1.20 & 1.59 & 6.0 & 0.22 & 266.6 & 17.9 & 101.5 \\
\hline \multicolumn{9}{|c|}{ NP1 (Nimaigarh Habigaon - Non-paddy soil): Dystric Eutrudepts } \\
\hline Ap & $0-33$ & 7.90 & 1.35 & 5.2 & 0.12 & 272.8 & 38.5 & 389.5 \\
\hline Bw1 & $33-55$ & 6.30 & 1.37 & 5.1 & 0.13 & 266.6 & 33.2 & 332.8 \\
\hline Bw2 & $55-80$ & 5.50 & 1.57 & 4.7 & 0.29 & 266.6 & 20.5 & 201.6 \\
\hline Bw3 & $80-100$ & 4.40 & 1.58 & 5.1 & 0.27 & 263.4 & 21.5 & 206.4 \\
\hline
\end{tabular}




\begin{tabular}{|c|c|c|c|c|c|c|c|c|}
\hline $2 \mathrm{Cg} 1$ & $100-190$ & 1.50 & 1.53 & 5.0 & 0.18 & 250.9 & 10.8 & 110.5 \\
\hline $2 \mathrm{Cg} 2$ & $190-220$ & 0.90 & 1.63 & 5.6 & 0.31 & 250.9 & 7.7 & 111.8 \\
\hline \multicolumn{9}{|c|}{ P2 (Silikha Sanaton - Paddy soil): Dystric Fluventic Eutrudepts } \\
\hline Ap & $0-15$ & 5.40 & 1.12 & 5.2 & 0.12 & 297.1 & 23.1 & 289.8 \\
\hline Bw & $15-55$ & 4.20 & 1.36 & 5.1 & 0.33 & 272.8 & 20.5 & 288.5 \\
\hline Bg1 & $55-90$ & 3.90 & 1.39 & 5.5 & 0.17 & 269.7 & 7.7 & 203.5 \\
\hline Bg2 & $90-125$ & 3.50 & 1.46 & 5.6 & 0.26 & 269.7 & 7.7 & 197.5 \\
\hline \multicolumn{9}{|c|}{ NP2 (Silikha Sanaton - Non-paddy soil): Dystric Eutrudepts } \\
\hline $\mathrm{Ap}$ & $0-10$ & 5.70 & 1.42 & 5.2 & 0.19 & 279.1 & 12.5 & 417.5 \\
\hline Bw1 & $10-35$ & 4.80 & 1.48 & 5.0 & 0.10 & 272.8 & 14.5 & 332.5 \\
\hline Bw2 & $35-90$ & 3.50 & 1.59 & 5.2 & 0.09 & 266.6 & 10.5 & 335.5 \\
\hline $2 \mathrm{C} 1$ & $90-115$ & 2.70 & 1.59 & 5.2 & 0.11 & 269.7 & 10.5 & 389.1 \\
\hline 3C2 & $115-165$ & 1.20 & 1.58 & 6.0 & 0.25 & 269.6 & 5.5 & 220.6 \\
\hline \multicolumn{9}{|c|}{ P3 (Khumtai - Paddy soil): Dystric Eutrudepts } \\
\hline$A p$ & $0-15$ & 5.40 & 1.42 & 5.1 & 0.10 & 283.2 & 25.6 & 432.5 \\
\hline Bw1 & $15-50$ & 4.20 & 1.52 & 5.5 & 0.14 & 272.8 & 20.5 & 389.5 \\
\hline Bw2 & $50-100$ & 2.70 & 1.70 & 5.5 & 0.13 & 279.1 & 12.8 & 201.1 \\
\hline Bw3 & $100-165$ & 1.60 & 1.52 & 5.5 & 0.25 & 269.7 & 10.3 & 334.5 \\
\hline $\mathrm{Bg}$ & $165-190$ & 1.00 & 1.53 & 5.5 & 0.17 & 263.4 & 7.7 & 201.1 \\
\hline \multicolumn{9}{|c|}{ NP3 (Khumtai - Non-paddy soil): Dystric Eutrudepts } \\
\hline $\mathrm{Ap}$ & $0-20$ & 6.30 & 1.39 & 5.7 & 0.15 & 282.2 & 23.1 & 160.7 \\
\hline$A B$ & $20-27$ & 5.40 & 1.17 & 5.7 & 0.22 & 254.0 & 12.8 & 357.8 \\
\hline Bw1 & $27-60$ & 2.70 & 1.44 & 4.9 & 0.14 & 266.6 & 10.1 & 331.5 \\
\hline Bw2 & $60-95$ & 1.70 & 1.46 & 5.2 & 0.33 & 235.2 & 10.1 & 257.6 \\
\hline Bw3 & $95-125$ & 1.50 & 1.70 & 5.2 & 0.28 & 272.8 & 7.7 & 349.5 \\
\hline
\end{tabular}

c) Available $\mathrm{N}, \mathrm{P}_{2} \mathrm{O}_{5}, \mathrm{~K}_{2} \mathrm{O}$

The data on available $\mathrm{N}, \mathrm{P}_{2} \mathrm{O}_{5}, \mathrm{~K}_{2} \mathrm{O}$ of the soils are presented in Table 5. The available nitrogen content of the soil varied from 263.4 to $297.1 \mathrm{~kg} \mathrm{ha}^{-1}$ in paddy soils and, 235.2 to $282.2 \mathrm{~kg} \mathrm{ha}^{-1}$ in non-paddy soils. The amount of available nitrogen was lower in surface horizons and it increased in the subsurface horizons except in NP3 soils. The surface horizons of paddy soils contained a higher (279.1-297.1 kg ha-1) amount of available nitrogen as compared to surface horizons of non-paddy soils (272.8-282.2 $\left.\mathrm{kg} \mathrm{ha}^{-1}\right)$. Nitrogen availability might have been as a result of more mineralization of soil organic carbon in the surface horizons of paddy soils during puddling and alternating oxidation-reduction conditions during rice cultivation, as suggested by Singh and Timsina (2005). However, more recent research proposed that soils under intensified wetland rice production systems showed mineralization to be insufficient and insignificant under these anaerobic conditions (Sahrawat, 2010). This was as a result of differences in activity of microorganisms functioning under aerobic and anaerobic conditions. The mineralization process is slower under anaerobic conditions due to less efficient and incomplete decomposition of organic matter (White and Reddy 2001).

Available $\mathrm{P}_{2} \mathrm{O}_{5}$ content of the soil varied from 7.7 to $28.2 \mathrm{~kg} \mathrm{ha}^{-1}$ in paddy soils and 5.5 to $38.5 \mathrm{~kg} \mathrm{ha}^{-1}$ in non-paddy soils. The surface horizons of paddy soils contained lesser amount of available $\mathrm{P}_{2} \mathrm{O}_{5}$ as compared to the surface horizons of nonpaddy soils except in soils of Nimaigarh Habigaon (P1, NP1). In general, the amount of available $\mathrm{P}_{2} \mathrm{O}_{5}$ was higher in the surface horizons, and it tended to decrease with soil depth.
Higher amounts of available $\mathrm{P}_{2} \mathrm{O}_{5}$ in the surface horizon might be as a result of an acidic $\mathrm{pH}$ on the surface horizons of these soils. In acid soils, $P$ is bound due to $\mathrm{Ca}, \mathrm{Al}$, and $\mathrm{Fe}$ ions, which make it readily adsorbed on clay surfaces.

Available $\mathrm{K}_{2} \mathrm{O}$ in soil varied from 101.5 to 432.5 $\mathrm{kg} \mathrm{ha}^{-1}$ in paddy soils and 110.5 to $389.5 \mathrm{~kg} \mathrm{ha}^{-1}$ in nonpaddy soils. The amount of available $\mathrm{K}_{2} \mathrm{O}$ was higher in surface horizons, and it decreased in subsurface horizons except in the NP3 profile. This increase in $\mathrm{K}_{2} \mathrm{O}$ in surface soils was indicative of soil organic carbon being responsible for available $\mathrm{K}_{2} \mathrm{O}$.

d) Exchangeable cations, cation exchange capacity (CEC) and base saturation

The data on exchangeable cations, cation exchange capacity (CEC), and percent base saturation are presented in Table 6.

The exchangeable $\mathrm{Ca}^{++}$was the dominant cation usually followed by exchangeable $\mathrm{Mg}^{++}, \mathrm{K}^{+}$, and $\mathrm{Na}^{+}$in the soils. The dominance of exchangeable $\mathrm{Ca}^{2+}$ in these soils is in general agreement with the findings of earlier workers on soils of Assam (Chakravarty et al., 1978; Dey and Sehgal, 1997; Karmakar and Rao, 1999a). Low amounts of exchangeable $\mathrm{Na}+$ and $\mathrm{K}+$ in these soils may be due to preferential losses of monovalent cations over divalent cations in leaching under high rainfall conditions. The amount of exchangeable $\mathrm{Ca}^{++}$ranged from 1.50-2.50 centimoles $\left(\mathrm{p}^{+}\right) \mathrm{kg}^{-1}$. The surface horizons of paddy soils contained lower amount of exchangeable $\mathrm{Ca}^{++}$(1.50-2.25 centimoles $\left.\left(\mathrm{p}^{+}\right) \mathrm{kg}^{-1}\right)$ as compared to the surface horizons of nonpaddy soils $\left(1.75-2.50\right.$ centimoles $\left(\mathrm{p}^{+}\right)$ $\mathrm{kg}^{-1}$ ). Zang and Chen (2009) reported $\mathrm{Ca}, \mathrm{Mg}$, and $\mathrm{Na}$ losses in the initial stage (50 yrs) of paddy cultivation 
with more gradual depletion with increasing paddy cultivation over time.

The amount of exch. $\mathrm{Mg}^{++}$ranged from 1.25 to 2.00 centimoles $\left(\mathrm{p}^{+}\right) \mathrm{kg}^{-1}$ in paddy soils and from 1.00 to 1.75 centimoles $\left(\mathrm{p}^{+}\right) \mathrm{kg}^{-1}$ in nonpaddy soils. The amount of exchangeable $\mathrm{Na}^{+}$ranged from 0.59 to 0.96 centimoles $\left(\mathrm{p}^{+}\right) \mathrm{kg}^{-1}$ in paddy soils and from 0.22 to 1.05 centimoles $\left(\mathrm{p}^{+}\right) \mathrm{kg}^{-1}$ in non-paddy soils. The amount of exchangeable $\mathrm{K}^{+}$ranged from 0.47 to 1.33 centimoles $\left(\mathrm{p}^{+}\right) \mathrm{kg}^{-1}$ in paddy soils and from 0.52 to 1.66 centimoles $\left(\mathrm{p}^{+}\right) \mathrm{kg}^{-1}$ in non-paddy soils.

The results concerning cation exchange capacity (CEC) of the soil profiles (Table 6) showed variations from 6.8 to 10.8 centimoles $\left(\mathrm{p}^{+}\right) \mathrm{kg}^{-1}$. Earlier studies revealed that the CEC of the alluvium-derived soils of Assam is low, and it is related to the dominance of low activity clay-like Kaolinite (Chakravarty and Barua, 1983; Karmakar and Rao, 1998; Dutta and Shanwal, 2006). These findings, therefore, suggested that silt and organic carbon contributed more CEC to these soils. Several researchers also reported that silt fractions contain sufficient negative charge and positively impacted CEC of soils (Leinweber et al., 1993; Caravaca et al., 1999; Karmakar, 2014). The base saturation of the soil varied from 52.0 to 68.2 percent (Table 6). Acidic soil conditions allowed for low base saturation levels in these soils; this was also a result of low CEC.

Table 6: Exchangeable cations, cation exchange Table capacity (CEC) and base saturation of the soils

\begin{tabular}{|c|c|c|c|c|c|c|c|c|}
\hline \multirow{3}{*}{ Horizon } & \multirow{3}{*}{ Depth (cm) } & \multicolumn{4}{|c|}{ Exchangeable bases } & \multirow{3}{*}{$\frac{\text { CEC }}{>}$} & \multirow{3}{*}{$\begin{array}{c}\text { Base } \\
\text { Saturation } \\
(\%)\end{array}$} & \multirow{3}{*}{$\begin{array}{l}\text { Exch. } \mathrm{Ca}^{++} \\
\text {Exch. } \mathrm{Mg}^{++}\end{array}$} \\
\hline & & $\mathrm{Ca}^{++}$ & $\mathrm{Mg}^{++}$ & $\mathrm{Na}^{+}$ & $\mathrm{K}^{+}$ & & & \\
\hline & & \multicolumn{4}{|c|}{ < - --------- $\mathrm{cmol}\left(\mathrm{p}^{+}\right) \mathrm{kg}^{-1}$} & & & \\
\hline \multicolumn{9}{|c|}{ P1 (Nimaigarh Habigaon - Paddy soil): Aquic Dystric Eutrudepts } \\
\hline Ap & $0-15$ & 2.00 & 1.75 & 0.88 & 1.20 & 9.2 & 63.4 & 1.14 \\
\hline Bw1 & $15-40$ & 2.00 & 1.75 & 0.83 & 1.25 & 8.8 & 66.2 & 1.14 \\
\hline Bw2 & 40-100 & 2.25 & 2.00 & 0.87 & 0.69 & 8.6 & 67.5 & 1.13 \\
\hline $2 \mathrm{Cg}$ & $100-120$ & 2.00 & 1.75 & 0.91 & 0.55 & 8.6 & 60.6 & 1.14 \\
\hline \multicolumn{9}{|c|}{ NP1 (Nimaigarh Habigaon - Non-paddy soil): Dystric Eutrudepts } \\
\hline Ap & $0-33$ & 2.50 & 1.75 & 0.34 & 0.94 & 10.8 & 51.2 & 1.43 \\
\hline Bw1 & 33-55 & 2.25 & 1.75 & 0.22 & 1.65 & 9.6 & 61.1 & 1.29 \\
\hline Bw2 & $55-80$ & 2.25 & 1.75 & 0.23 & 0.52 & 8.8 & 54.0 & 1.29 \\
\hline Bw3 & $80-100$ & 1.75 & 1.50 & 0.80 & 1.60 & 8.8 & 64.2 & 1.17 \\
\hline 2Cg1 & 100-190 & 1.75 & 1.50 & 1.00 & 0.58 & 8.6 & 56.2 & 1.17 \\
\hline 2Cg2 & 190-220 & 1.50 & 1.25 & 1.05 & 1.77 & 8.6 & 64.8 & 1.20 \\
\hline \multicolumn{9}{|c|}{ P2 (Silikha Sanaton - Paddy soil): Dystric Fluventic Eutrudepts } \\
\hline Ap & $0-15$ & 1.50 & 1.25 & 0.95 & 1.10 & 7.8 & 61.6 & 1.20 \\
\hline Bw & $15-55$ & 1.75 & 1.40 & 0.96 & 1.03 & 7.6 & 67.6 & 1.25 \\
\hline Bg1 & $55-90$ & 1.75 & 1.50 & 0.90 & 0.48 & 7.6 & 60.9 & 1.17 \\
\hline Bg2 & $90-125$ & 2.00 & 1.50 & 0.81 & 0.47 & 7.4 & 64.6 & 1.33 \\
\hline \multicolumn{9}{|c|}{ NP2 (Silikha Sanaton - Non-paddy soil): Dystric Eutrudepts } \\
\hline $\mathrm{Ap}$ & $0-10$ & 1.75 & 1.25 & 0.96 & 1.25 & 8.2 & 63.5 & 1.40 \\
\hline Bw1 & $10-35$ & 2.25 & 1.50 & 0.95 & 1.05 & 8.8 & 65.3 & 1.50 \\
\hline Bw2 & $35-90$ & 1.75 & 1.60 & 0.94 & 1.03 & 8.4 & 63.3 & 1.09 \\
\hline $2 \mathrm{C} 1$ & $90-115$ & 2.00 & 1.25 & 0.35 & 1.33 & 8.2 & 60.1 & 1.60 \\
\hline $3 \mathrm{C} 2$ & $115-165$ & 1.25 & 1.00 & 0.48 & 1.31 & 6.8 & 59.5 & 1.25 \\
\hline \multicolumn{9}{|c|}{ P3 (Khumtai - Paddy soil): Dystric Eutrudepts } \\
\hline Ap & $0-15$ & 2.25 & 1.25 & 0.92 & 1.50 & 9.0 & 65.8 & 1.80 \\
\hline Bw1 & $15-50$ & 2.25 & 2.00 & 0.75 & 1.14 & 9.0 & 68.2 & 1.13 \\
\hline Bw2 & $50-100$ & 2.00 & 1.75 & 0.90 & 0.11 & 7.8 & 61.1 & 1.14 \\
\hline Bw3 & $100-165$ & 1.50 & 1.25 & 0.59 & 1.33 & 7.8 & 59.9 & 1.20 \\
\hline $\mathrm{Bg}$ & $165-190$ & 1.50 & 1.25 & 0.59 & 1.13 & 7.4 & 60.4 & 1.20 \\
\hline \multicolumn{9}{|c|}{ NP3 (Khumtai - Non-paddy soil): Dystric Eutrudepts } \\
\hline $\mathrm{Ap}$ & $0-20$ & 2.50 & 1.75 & 0.60 & 0.63 & 8.8 & 62.3 & 1.43 \\
\hline$A B$ & $20-27$ & 2.50 & 1.25 & 0.81 & 1.07 & 8.5 & 66.2 & 2.00 \\
\hline Bw1 & $27-60$ & 2.25 & 1.50 & 0.93 & 0.91 & 8.4 & 66.6 & 1.50 \\
\hline Bw2 & $60-95$ & 1.50 & 1.00 & 0.75 & 1.33 & 8.8 & 52.0 & 1.50 \\
\hline Bw3 & $95-125$ & 1.50 & 1.00 & 0.70 & 1.66 & 8.6 & 56.5 & 1.50 \\
\hline
\end{tabular}

e) Soil classification

Based on morphological and physicochemical properties, the paddy and associated non-paddy soils were classified according to Table 7. These classifications were found to be Aquic Dystric
Eutrudepts (P1), Dystric Eutrudepts (NP1, NP2, P3, NP3), and Dystric Fluventic Eutrudepts (P2).

All the studied soils have Ochric diagnostic epipedons (horizon that forms near soil surface) and cambic diagnostic subsurface horizons. In these profiles 
clay content increased with soil depth, reached a maximum, and decreased after that. The subsurface horizons of P2, NP2 and, NP3 contained more than 1.2 times clay as compared to the respective surface horizons. However, clay cutans were absent in these soils. Therefore, the subsurface horizons of P2, NP2 and NP3 did not qualify as being argillic. The studied profiles belong to the order Inceptisols. Since the base saturation (by $1 \mathrm{~N} \mathrm{NH} 4 \mathrm{OAc}$ ) is 60 percent or more in one or more horizons at a depth between 25 and $75 \mathrm{~cm}$ from the mineral soil surface, then It can be said that all soils studied qualify for the great group Eutrudepts. All the soils do not have free carbonates throughout any horizon within $100 \mathrm{~cm}$ of mineral soil surface and therefore qualify for dystric characteristics at the subgroup level. In addition to dystric features, the soils of $\mathrm{P} 1$ have in one horizon within $60 \mathrm{~cm}$ of the mineral soil surface, redox depletions with chroma, and also aquic conditions for some time in typical years as indicated by presence of reddish-yellow mottles. The soils of P1 qualify for Aquic Dystric Eutrudepts at the subgroup level. The soils of P2, in addition to dystric characteristic, have more than 0.2 percent organic carbon at a depth of $125 \mathrm{~cm}$ below the mineral soil surface and also have a slope of less than 25 percent. The soils of P2 qualify for Dystric Fluventic Eutrudepts at the subgroup level. The profiles of NP1, NP2, P3, and NP3 qualify for Dystric Eutrudepts at the subgroup level.

Table 7: Classification of studied soils

\begin{tabular}{|c|c|c|c|c|}
\hline Pedons & Order & Suborder & Great group & Subgroup \\
\hline $\begin{array}{l}\text { P1 (Nimaigarh Habigaon } \\
\text { - Paddy soil) }\end{array}$ & Inceptisols & Udepts & Eutrudepts & $\begin{array}{l}\text { Aquic Dystric } \\
\text { Eutrudepts }\end{array}$ \\
\hline $\begin{array}{l}\text { NP1 (Nimaigarh Habigaon } \\
- \text { Non-paddy soil) }\end{array}$ & Inceptisols & Udepts & Eutrudepts & Dystric Eutrudepts \\
\hline $\begin{array}{l}\text { P2 (Silikha Sanaton - } \\
\text { Paddy soil) }\end{array}$ & Inceptisols & Udepts & Eutrudepts & $\begin{array}{l}\text { Dystric Fluventic } \\
\text { Eutrudepts }\end{array}$ \\
\hline $\begin{array}{l}\text { NP2 (Silikha Sanaton - } \\
\text { Non-paddy soil) }\end{array}$ & Inceptisols & Udepts & Eutrudepts & Dystric Eutrudepts \\
\hline P3 (Khumtai - Paddy soil) & Inceptisols & Udepts & Eutrudepts & Dystric Eutrudepts \\
\hline $\begin{array}{l}\text { NP3 (Khumtai - Non- } \\
\text { paddy soil) }\end{array}$ & Inceptisols & Udepts & Eutrudepts & Dystric Eutrudepts \\
\hline
\end{tabular}

\section{Summary And Conclusion}

\section{a) Morphological characteristics}

1. Soil color varied from light olive-brown to yellow with a dominant hue of 10YR, a value ranging from 5 to 8 and chroma from 1 to 8 .

2. Reddish-yellow mottles had been observed in the subsurface horizons of the soils, indicating oxidation-reduction cycles.

3. The texture of the soils ranged from loamy sand to clay loam.

4. The structure of the soils ranged from massive to sub-angular blocky. Surface horizons of paddy soils exhibited massive soil structure.

b) Mechanical composition

5. Sand content varied from 29.5-60.9 percent in the surface and 27.5-55.8 percent in the subsurface horizons of paddy soils, and 31.8-56.4 percent in the surface and 27.0-84.2 percent in the subsurface horizons of nonpaddy soils.

6. Silt content varied from 20.0-35.0 percent in the surface and 18.6-35.5 percent in the subsurface horizons of paddy soils, and 21.1-38.1 percent in the surface and 8.2-40.5 percent in the subsurface horizons of nonpaddy soils.

7. Clay content varied from 18.7-35.5 percent in the surface and 25.6-38.5 percent in the subsurface horizons of paddy soils, and 22.5-30.1 percent in the surface and 7.6-33.5 percent in the subsurface horizons of nonpaddy soils.

8. Sand content was negatively and significantly correlated with silt $\left(r=-0.958^{\star *}\right)$ and clay $(r=-$ $\left.0.927^{\star *}\right)$.

\section{c) Physico-chemical properties}

9. Organic carbon content in soil varied from 5.40-7.90 $\mathrm{g} \mathrm{kg}^{-1}$ in the surface and $0.90-6.30 \mathrm{~g} \mathrm{~kg}^{-1}$ in the subsurface horizons. The amount of organic carbon was found to be lower (5.40-6.20 g kg-1) in the surface horizons of paddy soils in comparison to that in the surface horizons of nonpaddy soils (5.70$\left.7.90 \mathrm{~g} \mathrm{~kg}^{-1}\right)$. Organic carbon content decreased with soil depth.

10. The bulk density of soils varied from $1.12-1.42 \mathrm{~g} / \mathrm{cc}$ in the surface and 1.17-1.70 $\mathrm{g} / \mathrm{cc}$ in the subsurface horizons. Bulk density of soils increased with soil depth.

11. The $\mathrm{pH}$ of the soils (1:2.5 soil: water ratio) varied from 4.6-5.7 in the surface and 4.7-6.0 in the subsurface horizons. The $\mathrm{pH}$ of the soil manifested a negative correlation with organic carbon $\left(r=-0.459^{\star}\right)$.

12. The electrical conductivity of soil was low (0.09-0.33 $\mathrm{dSm}^{-1}$ ) in the studied soils.

13. Available nitrogen content of the soil varied from 263.4 to $297.1 \mathrm{~kg} \mathrm{ha}^{-1}$ in paddy soils, and 235.2 to $282.2 \mathrm{~kg} \mathrm{ha}^{-1}$ nonpaddy soils. The amount of available nitrogen was lower in surface horizons and 
it increased in subsurface horizons except in NP3 profiles.

14. Available $\mathrm{P}_{2} \mathrm{O}_{5}$ content of the soil varied from 7.7 to $28.2 \mathrm{~kg} \mathrm{ha}^{-1}$ in paddy soils, and 5.5 to $38.5 \mathrm{~kg} \mathrm{ha}^{-1}$ in nonpaddy soils. The amount of available $\mathrm{P}_{2} \mathrm{O}_{5}$ was higher in the surface horizons and it tended to decrease with soil depth.

15. Available $\mathrm{K}_{2} \mathrm{O}$ in soil varied from 101.5 to $432.5 \mathrm{~kg}$ $\mathrm{ha}^{-1}$ in paddy soils and 110.5 to $389.5 \mathrm{~kg} \mathrm{ha}^{-1}$ in nonpaddy soils. The amount of available $\mathrm{K}_{2} \mathrm{O}$ was higher in surface horizons and it decreased in subsurface horizons except NP3 soils.

16. The exchangeable $\mathrm{Ca}^{++}$was the dominant cation (1.25-2.50 centimoles $\left.\left(\mathrm{p}^{+}\right) \mathrm{kg}^{-1}\right)$ followed by exchangeable $\mathrm{Mg}^{++}(1.00-2.00 \quad$ centimoles $\left.\left(\mathrm{p}^{+}\right) \mathrm{kg}^{-1}\right)$, exchangeable $\mathrm{K}^{+}(0.11-1.77$ centimoles $\left.\left(\mathrm{p}^{+}\right) \quad \mathrm{kg}^{-1}\right)$ and, exchangeable $\mathrm{Na}^{+}$(0.35-1.05 centimoles $\left.\left(\mathrm{p}^{+}\right) \mathrm{kg}^{-1}\right)$.

17. The surface horizons of paddy soils contained lower amount of exchangeable $\mathrm{Ca}^{++}$(1.50-2.25 centimoles $\left.\left(\mathrm{p}^{+}\right) \mathrm{kg}^{-1}\right)$ as compared to the surface horizons of nonpaddy soils $(1.75-2.50 \mathrm{c} \mathrm{mol}$ $\left.\left(\mathrm{p}^{+}\right) \mathrm{kg}^{-1}\right)$.

18. The cation exchange capacity of soil varied from 7.4-10.8 centimoles $\left(\mathrm{p}^{+}\right) \mathrm{kg}^{-1}$, and base saturation varied from 52.0-68.2 percent.

d) Soil classification

19. Generally, based on the morphological and physico-chemical properties, the soil profiles were classified as Aquic Dystric Eutrudepts (P1), Dystric Eutrudepts (NP1, NP2, P3, NP3) and Dystric Fluventic Eutrudepts (P2).

\section{BiBLIOGRAPHY}

1. Balthazar. M.et.al. (2016). Morphology, Genesis, Physico-chemical Properties, Classification and Potential of Soils Derived from Volcanic Parent Materials in Selected Districts of Mbeya Region, Tanzania. International journal of plant and soil science 10(4): 1-19.

2. Barshad,I.(1964). Chemistry of soil development.In: Chemistry of the soil.Bear, F.E.(ed.). $2^{\text {nd }}$ Edition. Oxford and IBH publishing Co., New Delhi, pp. 1-70

3. Baruah, B.K., Chakravarty,D.N. and Karmakar,R.M. (1996). Variability of soils in two rice growing toposequences. Journal of the Indian Society of Soil Science 44(4): 690-694.

4. Brinkman, R. (1970). Ferrolysis, a hydromorphic soil forming process. Geoderma 3: 199-206.

5. Chakravarty, D.N., Sehgal, J.L and Dev, G. (1978). Influence of climate and topography on the pedogenesis of alluvium derived soils in Assam: Geographical settings, morphological and physicochemical properties. Indian journal of Agricultural Chemistry. 11:77-97.
6. Das, K.N. (1990). Characterisation and Classification of some typical paddy growing soils of Assam. M. Sc. (Agri.) Thesis, Assam Agricultural University Jorhat.

7. Dey, J.K. (1987). Pedogenesis and classification of some submerged soils of Assam and their sustainability for rice cultivation. Ph.D. Thesis, P.A.U.,Ludhiana.

8. Dey, J.K. and Sehgal, J.L. (1997). Characteristics and classification of some alluvial derived paddy and associated non-paddy soils of Assam. Agropedology 7:22-31.

9. Dutta, M. (2001). Pedogenic evaluation of Fe, Al and $\mathrm{Mn}$ in soils under paddy and non-paddy land uses. M.Sc. (Agri) Thesis, Assam Agric. Univ., Jorhat.

10. Fukushi, S. and Iwama, H. (1982). On the distribution of paddy soils in Muda irrigation area- a detailed soil survey of ACRBD-4 Block. JARQ 16:64-71

11. Gangopadhyay, S.K.,Walia, C.S., Chamuah, G.S. and Baruah, U. (1998). Rice growing soils of Upper Brahmaputra Valley of Assam - their characteristics and suitability. Journal of Indian Society of soil science 46:103-109.

12. Grant, C.J. (1965). Soil characteristics associated with the wet cultivation of rice. In: The Mineral Nutrition of Rice Plant. John Hopkins, Baltimore. Pp 15-28.

13. Hassannezhad, H., Pashaee, A., Khormali, F. and Mohammadian, M. (2008). Morphology and micromorphology of paddy soils under different soil moisture regime and ground water table in Mazandaran province, Northern Iran, Amol. International Journal of Soil Science 3(3): 149 -156.

14. Kalbitz, K. et al. The carbon count of 2000 years of rice cultivation. Global Change Biol. 19, 1107-1113 (2013).

15. Kanno, I (1956). A scheme for soil classification of paddy fields in Japan with special reference to mineral paddy soil. Soil plant food 2:148-152.

16. Kanno, I., Honjo, Y., Arimura, S. and Tokudome, S. (1964). Genesis and characteristics of rice soils developed on polder lands of the Shiroshi area, Kyushu. Soil Science and Plant Nutrition 10:1-19.

17. Karmakar, R.M. and Rao, A.E.V. (1999a). Soils on different physiographic units in Lower Brahmaputra Valley zone of Assam. I. Characterization and classification. Journal of the Indian Society of soil science 47: 761-767.

18. Katou,H., Nakaya, N. and Maeda, K. (1985). Changes in sediment volume, liquid limit and plastic limit of Alluvial soils upon drying. Soil Science and Plant Nutrition 31: 215-226.

19. Kongel-Knabner, I., Amelung, W., Cao, Z., Fiedler, S. and Frenzel, $P$ (2010). Biogeochemistry of paddy soils. Geoderma 157:1-14. 
20. Kurniati et.al.(2016). Characterization of Several Paddy Soil Types in Bogor, West Java, Indonesia. Department of Soil Science and Land Resource, Bogor Agricultural University Bogor 16680, Indonesia p. 05.

21. Mitsuchi,M. (1974). Characters of humus formed under rice cultivation. Soil Science and Plant Nutrition 20: 249-259.

22. Moormann, F.R.(1981). The classification of Paddy soils as related to soil taxonomy. In: paddy Soils. Institute of Soil Science, Academic Sinica, Nan Jing. China, pp. 139-150.

23. Moormann, F.R. and Dudal, R. (1964). Characteristics of soils on which paddy is grown in relation to their capability classification. International Rice Comm. Working Party on Rice, soils, Water and Fertilizer practices, Manila Philippines, p 18.

24. Moormann, F.R. and van Breeman, N. (1978). Rice: Soil, Water and Land. IRRI, Los Banos, Philippines, p 185.

25. Motomura, S., Lapid,F.M. and Yokoi,H. (1970). Soil structure development in Ariake Polder soils in relation to iron forms. Soil Science and Plant Nutrition 16:47-54.

26. Okajima, H. and Imai (1981). Some Chemical Properties of soils from the Taoyuan Prefecture, China, in soils. National Institute of soil science, Academia Sinica, Nanjing, China, p 444-448.

27. Ponnamperuma, F.N., Martinery, E. and Loy, T.N. (1966). Influence of redox poteniial and partial pressure of carbondioxide on $\mathrm{pH}$ values and the suspension effect of flooded soil. Soil science 101: 421-431.

28. Prasad, Jagdish and Jondhale, D.G. (2006). Characteristics of rainfed rice and associated non rice shrink-well soils in Central India. Clay Research 25(1):55-67

29. Sahrawat. K.L. (2010) Nitrogen mineralization in lowland rice soils: The role of organic matter quantity and quality. Archives of Agronomy and Soil Science Vol. 56, No. 3,pg. 337-353.

30. Singh.Y., Timsina. J. (2005). Crop residue management for nutrient cycling and improving soil production in rice based cropping systems in the tropics. Science Direct Journal and books, Advances in Agronomy. pg 124-128.

31. Somasiri, S. (1985). Wet Alfisols with special reference to Sri Lanka. Proc. Symp. Wetland solis: Characterization, Classification and Utilization. IRRI, Los Banao, Philippines, pg. 421-438.

32. Stout, B.A. (1966). Equipment for rice production. FAO Agricultural Development paper 84,p 169.

33. Smita Tale and Sangita Ingole (2015). A Review on Role of Physico-Chemical Properties in Soil Quality. Chemical science Review and Letters pg 57.
34. Van Veen, J.A., Ladd, J.N. and Frissel, M.J. (1984). Modelling $\mathrm{C}$ and $\mathrm{N}$ turnover through the microbial biomass soil. Plant Soil 76:257-274.

35. Wei Zhou, Teng-Fei Lv, Yong Chen, Anthony P. Westby (2014). Soil Physicochemical and Biological Properties of Paddy-Upland Rotation: A Review. Scientific World Journal Volume 2014, Article ID 856352.

36. White JR, Reddy KR. (2001). The effects of select electron acceptors on organic nitrogen mineralization in northern Everglades soils. Soil Sci Soc Am J. 65:941-948.

37. Xi,Z. (1981). On the tendancy of organic matter accumulation in paddy soil under triple cropping system in suburbs of Shanghai. Proc. Symp. Paddy soils, Institute of Soil Science, Nanjing, China, $\mathrm{p}$ 471-474.

38. Zang, Gan-Lin and Chen, Liu-Mei. (2009). Soil genesis along a paddy soil chronosequence in a millennium scale. $19^{\text {th }}$ World Congress of Soil Science, soil solutions for a changing World, 1-6 August 2010, Brisbane Australia. 